\title{
EFFICIENCY OF PHARMACEUTICAL CONSUMPTION IN TURKEY: BENCHMARKING WITH OECD BY DEA ${ }^{1}$
}

\author{
Çağla Pınar BOZOKLU² \\ Yasemin KESKİN BENLİ ${ }^{3}$
}

\author{
Received Date (Başvuru Tarihi): 01/11/2018 \\ Accepted Date (Kabul Tarihi): 15/11/2018 \\ Published Date (Yayın Tarihi): 30/11/2018
}

\begin{abstract}
After 1980s, consumers begin to focus more health-conscious behaviours and attitudes including the concept of consuming pharmaceutical products. Pharmaceutical consumption attitude is a natural outcome of this trend. In this research, it is aimed to analyze Turkey's benchmarking position among OECD countries in terms of pharmaceutical consumption efficiency. 15 OECD countries' 5 years (2008-2012) analyzed by DEA-Malmquist TFP with the outputoriented and variable returns to scale methods. TC index shows that Turkey had created more pharmaceutical consumption and longer life expectancy by using same amount of number of physicians, number of pharmacists, total public and private health insurance expenditures and number of doctor consultations. By the way, Turkey had embraced efficiency growth with the rate of 0.4 percent. However, total efficiency level of Turkey got damaged by reason of its administrative limitations.
\end{abstract}

Keywords: Pharmaceutical Consumption; Life Expectancy; DEA

JEL Codes: E21, I131, C61, C33

\section{TÜRKIYYE'DE ILAÇ TÜKETIMININ VERIMLILİ̆̇i: VZA YÖNTEMİ İLE OECD ÜLKELERİ KARŞILAŞTIRMASI}

ÖZ

1980’lerden sonra, tüketiciler ilaç tüketimi de dahil olmak üzere, daha bilinçli bir şekilde sağllk odaklı davranışlar ve tutumlar geliştirmeye başlamıştır. İlaç tüketimi tutumu bu eğilimin doğal bir sonucudur. Bu araştırmada Türkiye’nin OECD ülkelerine arasında ilaç tüketimi verimliliği açısından karşılaştırmalı konumunun analiz edilmesi amaçlanmaktadır. 15 OECD ülkesinin 5 yıllık (2008-2012) panel verisi çıktı odaklı ve ölçeğe göre değişken getiri yöntemleri ile uygulanmışVZA-Malmquist TFV ile ölçülmüş̧ür. Teknolojik değişim indeksi, Türkiye'nin aynı miktarda hekim, eczacı, sağllk sigorta harcaması (devlet ve özel) ve doktor muayenesi ile hem daha fazla ilaç tüketimi hem de daha uzun bir yaşam süresi beklentisi ortaya koyduğunu göstermektedir. Bu yıllar arasında Türkiye \%0.4 verimlilik artışı yaratmıştır. Ancak, Türkiye'nin toplam verimlilik seviyesi yönetsel sınırlılıklardan ötürü düşüktür.

Anahtar Kelimeler: İlaç Tüketimi, Hayat Beklentisi, VZA

JEL Kodları: E21, I131, C61, C33

\footnotetext{
${ }^{1} \mathrm{Bu}$ çalışma "Business and Organization Research Conference-BOR 2018” adlı kongrede yayınlanmıştır.

${ }^{2}$ Dr. Öğr.Üyesi, Başkent Üniversitesi, cpbozoklu@baskent.edu.t

https://orcid.org/0000-0002-4147-9519

${ }^{3}$ Prof. Dr., Ankara Hacı Bayram Veli Üniversitesi, ykeskin@gazi.edu.tr https://orcid.org/0000-0002-8386-2620
} 


\section{INTRODUCTION}

During the 1980s, consumers begin to focus more health-conscious behaviours and attitudes for having a longer quality living. They have a penchant to change the way that they live by doing more and regular exercises or sports, quitting or reducing the consumption of tobacco and alcohol products. Moreover, they may show more proactive responses in the concept of healthcare choices. Pharmaceutical consumption attitude is a natural outcome of this trend that is identified the wellness and health maintenance behaviours as 'proactive', whereas traditional treatment or cure seeking behaviours are titled 'reactive'. This trend shapes up a new concept, 'expert patient', who can manage their own illnesses and conditions by developing knowledge relevant to maintaining health and countering illness (Shaw and Baker, 2004). Within this circumstances, not only the pharmaceutical companies but also global health economy has transformed.

Within the perspective of health economics, there are some researches integrating a range of literatures from the social sciences, health economics and business and health services provide valuable insights about various countries (Frech and Miller, 2004; Cremieux et al. 2005; Dormont, Grignon and Huber, 2006; Rüütel and Pudersell. 2011; Van Boeckel et al., 2014). However most of them focus and analyse only one country's position in a global health sector. There are a few researches that analyse Turkey's position in this market and the majority of them do not provide a benchmark with the developed countries.

\section{PHARMACEUTICAL CONSUMPTION}

In the 1990s, new kind of pharmaceuticals, which target enhancing humans' life quality without a purpose of curing any serious disease, has developed. Lexchin (2001, 1449) categorized these lifestyle drugs into two clusters: (a) fall into the border zone between the medical and social definitions of health (e.g. male hair loss); (b) treat diseases that derive from a person's lifestyle choices (e.g. obesity or nicotine addiction). It is not clear that lifestyle drugs can improve a person's life expectancy, even they have been commercialized as a back-up for activities of daily life.

According to the wide range researches, transformation of the patients' qualification has effected the variables of life expectancy in terms of differentiate the attitudes of patient towards physicians and health insurance companies. Common assumption is depending on the idea that the increasement of pharmaceutical expenditures (public and private), insurance expenditures, number of practising physician, number of practising pharmacists, number of doctor consultations influences positively human kinds' life expectancy as years. The rise of pharmaceutical consumption is a social concept, which should be discussed in terms of both costs and benefits. And it also has taken into hand 
differently among countries depending on their specific economic conditions. For example, Patented Medicine Prices Review Board (1992-1998) had conducted a research, the cost driver analysis project, in Canada which is a socially and economically developed country and found that 'changes in utilization and the availability of newer therapies were the major cost drivers, and that price changes (at the drug level) did not play a significant role in driving expenditures' (Cremieux et al. 2005, 107). On the other hand, in developing countries like Bangladesh, consumption of pharmaceuticals should be discussed in a peculiar perspective. For example, in Bangladesh, a large portion of population had limited access to modern drugs (\%30-\%85) until new national pharmaceutical policy was rapidly introduced (a huge reform) in 1982 (Reich, 1994, 130).

Since 1980s, the proportion of total health expenditure to gross domestic product (\%) and the competition has increased in Turkey. In the 1990s, limited number of private hospitals entered the market. As an extension of health-conscious trend, $67 \%$ of the new hospitals are the private enterprises (Özdemir, Kılıç and Aydın, 2010, 5). On the other hand, Social Security Institution (SSI) released an additional statement titled 'Complementary or Supportive Health Insurance' (No.B.13.2.SGK.0.11.05.03/674) on the date of 28.06.2012. This kind of insurance provides an extra coverage for the healthcare services that general health insurance does not cover partially or fully. Depending on these improvements, Turkish Statistical Institute (TSI) reported that total health expenditures have regularly expanded in Turkey since the year of 2000 (TSI, 2017).

Within this perspective, it could not be clearly understood that the increasement of pharmaceutical consumption in Turkey has demonstrated a normal trend in a manner of technical or operating efficiency comparing to other developed countries such as OECD countries. In this research, pharmaceutical consumption trends of OECD countries including Turkey are analysed by means of DEA-Malmquist analysis for determining the relative position of Turkey.

\section{METHOD}

Recent years have seen a great variety of applications of DEA (Data Envelopment Analysis) for use in benchmarking the performances of many different kinds of entities engaged in many different sectors among different countries. It has a widespread utilization because of the complex (often unknown) nature of the relations between the multiple inputs and multiple outputs involved (Cooper, Seiford and Tone, 2007).

DEA is a nonparametric linear programming method for assessing the efficiency and productivity of DMUs. DEA allows multiple inputs-outputs to be considered at the same time without any assumption on data distribution. In each case, efficiency is measured in terms of a proportional change in inputs or outputs. A DEA model can be subdivided into an input-oriented model, which 
minimizes inputs while satisfying at least the given output levels, and an output-oriented model, which maximizes outputs without requiring more of any observed input values (Benli and Bozoklu, 2016). DEA models can also be subdivided in terms of returns to scale by adding weight constraints. Charnes and his colloquies (1978) originally proposed the efficiency measurement of the DMUs for constant returns to scale (CRS), where all DMUs are operating at their optimal scale. Later Banker, Charnes, and Cooper (1984) introduced the variable returns to scale (VRS) efficiency measurement model, allowing the breakdown of efficiency into technical and scale efficiencies (Ji and Lee, 2010).

The DEA has been employed for analysing efficiency of health facilities founded in both developed and developing countries (e.g. Ersoy et al. 1997; Parkin and Hollingsworth, 1997; Hollingsworth and Parkin, 1997; Thanassoulis et al. 1995; Kooreman, 1994; Majumdar, 1994; Ozcan and Bannick, 1994; Ozcan, Mccue and Okasha, 1996; Huang, 1986; Huang, 1990). However, researches using panel data of health economics preferred to employ Malmquist method (RetzlaffRoberts, Chang and Robin, 2004; El-Shinnawy, 2010; Song and Zhang, 2013; Lin and Hong, 2015).

Static efficient analyses which focus only the performance of one year cannot maintain sufficient results in terms of benchmarking. For example, DEA analysis gives insights about a company's relative efficiency scores for one operational term however it does not produce any information on total factor productivity among years. The method integrating both DEA and The Malmquist Index (TMI), introduced by Malmquist (1953) in a consumption context, provides useful observations about changes of total factor productivity (TFP) among years. The MPI can classify the findings as efficiency change, technical change and TFP growth sub-units. The software DEAP which has been developed by Coelli (1996) has been used to compute the indices.

Findings are interpreted according to score of TFP. When TFP is bigger than ' 1 ', efficiency increases (Kesbiç, Tokatlığlu and Ürüt, 2004, 73). TFP index allows separating technological change (TC) and technical efficiency change (EC). It is also measured by multiplying EC with TC (Angelidis and Lyroudi, 2005). In the case of EC and TC is bigger than ' 1 ', DMU's productivity and efficiency respectively increase. According to Karacabey $(2002,75)$, negative changes in TC may represent that lesser output is produced with the same inputs.

EC can be further decomposes into pure technical efficiency (PEC) and scale efficiency change (SEC). EC can be measured by multiplying PEC with SEC similarly. PEC and SEC test whether DMU operates with the optimum managerial effectiveness and production capacity respectively (Keskin Benli, 2006; Keskin and Degirmen, 2013). If either PEC or SEC is smaller than ' 1 ', it is meant that there are some problems about managerial effectiveness or efficiency of production capacity (Keskin Benli, 2012). All of these efficiency components can be measured by Malmquist TFP index and it is crucial for determining the antecedents of efficiency scores (Deliktaş, 2002, 263). 
This research employs DEA-Malmquist TFP with the output-oriented and variable returns to scale methods, to obtain the Malmquist productivity index at the country-level for a representative sample of OECD countries and their pharmaceutical industry data during a study period which extends between 2008 and 2012. Output oriented is selected in order to researchers agree to general assumption that pharmaceutical consumption will assist curing diseases and having a longer life. Variable returns to scale is also utilized because the main research question is whether the increasement of pharmaceutical consumption in Turkey has demonstrated a normal trend in a manner of technical or operating efficiency comparing to OECD countries. Output and input variables are selected as demonstrated on Table 1. Data was obtained from the various links of OECDdata.com. Research period has to be limited due to some countries could not / would not collect and publish the related data after the year of 2012. Within the context of limitation, researchers did not prefer to reduce DMU (country) number from 15 by reason that it would undermine the structure of model. Normally, the number of DMUs should be larger than the total number of inputs and outputs (Liu, Ding and Lall, 2000,145, Boussofiane, Dyson and Thanassoulis, 1991,7-8).

Table 1. Output And Input Variables

\begin{tabular}{cc}
\hline Output & Input \\
\hline Pharmaceutical Consumption (\$ at exchange rate) & Total Public and Private Health Insurance \\
Pharmaceutical Sales (\$ at exchange rate) & Practising Physicians (Number per Capita) \\
Life Expectancy of Woman (Years) & Practising Pharmacists (Number per Capita) \\
Life Expectancy of Man (Years) & Doctor Consultations (Number per Capita) \\
Population of 65 years old and over & \\
$(\%$ of Total Population) &
\end{tabular}

\section{FINDINGS}

Between the years of 2008 and 2012, efficiency results of fifteen OECD countries are given as EC, TC, PEC, SEC and TFP on Table 2.

According to Table 2, EC had not differentiated between the years of 2008-2012. 74\% of countries' (Denmark, Estonia, Finland, Germany, Iceland, Korea, Luxembourg, Netherlands, Norway, Slovenia and Sweden) EC index had not changed. Czech Republic's and Portugal's (13\% of countries) EC index had growth as $0.4 \%$ and $0.1 \%$ respectively. On the other hand, Hungary's and Turkey's (13\% of countries) EC index had diminished as $0.1 \%$ and $1 \%$ respectively. Hungary's poor efficiency index was derived from the downtrend of SEC index. The reason of the Turkey's EC index was the fall down 
of the PEC index. In a general manner, Czech Republic was the most efficient country whereas Turkey was the most inefficient one.

Table 2. TFP And Related Efficiency Index Of 15 OECD Countries (2008-2012)

\begin{tabular}{|c|c|c|c|c|c|c|}
\hline \multicolumn{2}{|c|}{ DMUs (Country) } & \multirow{2}{*}{$\frac{\text { EC }}{1.004}$} & \multirow{2}{*}{$\begin{array}{c}\text { TC } \\
1.003\end{array}$} & \multirow{2}{*}{$\begin{array}{l}\text { PEC } \\
1.003\end{array}$} & \multirow{2}{*}{$\begin{array}{l}\text { SEC } \\
1.001\end{array}$} & \multirow{2}{*}{$\begin{array}{l}\text { TFP } \\
1.007\end{array}$} \\
\hline 1 & Czech Republic & & & & & \\
\hline 2 & Denmark & 1.000 & .998 & 1.000 & 1.000 & .998 \\
\hline 3 & Estonia & 1.000 & 1.016 & 1.000 & 1.000 & 1.016 \\
\hline 4 & Finland & 1.000 & 1.050 & 1.000 & 1.000 & 1.050 \\
\hline 5 & Germany & 1.000 & .995 & 1.000 & 1.000 & .995 \\
\hline 6 & Hungary & .999 & 1.006 & 1.000 & .999 & 1.005 \\
\hline 7 & Iceland & 1.000 & 1.014 & 1.000 & 1.000 & 1.014 \\
\hline 8 & Korea & 1.000 & 1.009 & 1.000 & 1.000 & 1.009 \\
\hline 9 & Luxembourg & 1.000 & .994 & 1.000 & 1.000 & .994 \\
\hline 10 & Netherlands & 1.000 & .963 & 1.000 & 1.000 & .963 \\
\hline 11 & Norway & 1.000 & .970 & 1.000 & 1.000 & .970 \\
\hline 12 & Portugal & 1.001 & 1.015 & 1.000 & 1.001 & 1.016 \\
\hline 13 & Slovenia & 1.000 & 1.013 & 1.000 & 1.000 & 1.013 \\
\hline 14 & Sweden & 1.000 & 1.002 & 1.000 & 1.000 & 1.002 \\
\hline 15 & Turkey & .990 & 1.004 & .979 & 1.011 & .994 \\
\hline & Mean & 1.000 & 1.003 & .999 & 1.001 & 1.003 \\
\hline
\end{tabular}

TC index had growth $0.3 \%$ between the years of $2008-2012.67 \%$ of countries' (Czech Republic, Estonia, Finland, Hungary, Iceland, Korea, Portugal, Slovenia, Sweden and Turkey) TC index had raised and Denmark's, Germany's, Luxembourg's, Netherland's and Norway's (33\% of countries) TC index had dropped. Finland was the best country on TC index (0.5\% growth) whereas Portugal was the worst one (fall down $0.37 \%$ ). Depending on that, Finland had produced more output by means of utilizing same amount of input.

Between the years of 2008-2012, TFP index had improved $0.3 \%$. More than the nearly half of countries' (Czech Republic, Estonia, Finland, Hungary, Iceland, Korea, Portugal, Slovenia and Sweden) TFP index had boosted and Denmark's, Germany's, Luxembourg's, Netherland's, Norway's and Turkey's (40 \% of countries) TFP index had weakened. Czech Republic and Portugal had growth 
their TFP index via by both EC and TC, whereas Estonia, Finland, Hungary, Iceland, Korea, Slovenia and Sweden had increased their TFP index by only TC. Netherland was the country which had experienced the most falloff with the rate of $0.37 \%$. Changes of countries' TFP index between the years of 2008-2012 are presented on Table 3.

According to Table 3, average annual growth of EC index had not changed between the years of 2009 and 2012. Among 15 OECD countries, EC index had shown an increasing trend with the rate of $0.1 \%$ in 2012 in spite of it had dropped $0.2 \%$ in 2011. As a contrast, TC index had experienced relatively lower efficiency level in $2009(99.5 \%)$ but it had improved $2.7 \%$ until the end of the year 2011. As a result, TFP index had developed with the efficiency rate of $2.2 \%$ in the same year (2011). However, TFP index had reduced in other years. The mean index value of TFP of 15 OECD countries among these years is found as 1.003 and it indicates that total factor productivity had enhanced with a ratio of $0.3 \%$.

Table 3. TFP And Related Efficiency Index of 15 OECD Countries (2008-2012)

\begin{tabular}{lccccc}
\hline Years & EC & TC & PEC & SEC & TFP \\
\hline $\mathbf{2 0 0 9}$ & 1.000 & .995 & 1.000 & 1.000 & .995 \\
$\mathbf{2 0 1 0}$ & 1.000 & 1.000 & .998 & 1.002 & .999 \\
$\mathbf{2 0 1 1}$ & .998 & 1.022 & .997 & 1.001 & 1.020 \\
$\mathbf{2 0 1 2}$ & 1.001 & .997 & 1.001 & 1.000 & .997 \\
\hline Mean & 1.000 & 1.003 & .999 & 1.001 & 1.003 \\
\hline
\end{tabular}

Note: All Malmquist Index averages are geometric means.

\section{CONCLUSION}

Depending on the emerging of healthy lifestyle trend during 1980s, patients have developed more conscious and reactive attitudes towards pharmaceutical consumption. This trend has also encouraged companies for producing distinctive kinds of pharmaceuticals called 'lifestyle drugs'. This situation creates a circle which assists and promotes consumption of all kinds of pharmaceuticals with the approval of national and/or international health policies.

OECD health data has reported a remarkable growth trend on pharmaceutical consumption rates among member and non-member countries. However, it does not indicate that the developing growth rates of consumption has an efficient impact on lifetime expectancy. DEA integrated with Malmquist Index analysis is a nonparametric linear programming method for assessing the efficiency 
and productivity of various kinds of DMUs such as institutions and companies among years. In this research, panel data of 15 OECD countries on health statistics analysed for determining Turkey's benchmarking position in terms of pharmaceutical consumption efficiency (2008-2012) by means of DEA-Malmquist TFP.

Findings reveal that most of the OECD countries had worked at the $100 \%$ managerial efficiency level between the years of 2008 and 2012 with the exception of Czech Republic and Turkey (see Table 2. PEC index). Czech Republic had enhanced managerial efficiency $0.3 \%$ whereas Turkey had dropped behind $2.1 \%$. In contrast to this result, Turkey is the country which improved its scale efficiency most. It is clearly seen that efficiency level of Turkey on pharmaceutical consumption would be quite more than other OECD countries if its' resources allocated and managed more efficiently. Moreover, TC index shows that Turkey had created more pharmaceutical consumption and longer life expectancy by using same amount of input (number of physicians, number of pharmacists, total public and private health insurance expenditures and number of doctor consultations). By the way, Turkey had embraced efficiency growth with the rate of $0.4 \%$. In a general manner, total efficiency level of Turkey got harmed by reason of its administrative limitations.

On the other hand, the negative effects of the economic crisis which made its presence felt slightly in 2009 in Turkey easily can be seen on Table 3. Following years (2010 and 2011) TFP and PEC indexes had strikingly dropped but that downtrend was observed solely in Turkey among selected 15 OECD countries.

This research maintains valuable insights on Turkey's benchmarking position among OECD countries in terms of pharmaceutical consumption efficiency despite of the fact that it could not produce comparative strategical suggestions for improving its managerial efficiency. One important avenue for the future researches is to analyse the most descriptive variables on lifetime expectancy depending on the pharmaceutical consumption via by compared to most efficient country (Finland TFP growth $=0.5 \%$ ) among OECD countries. Thereby, independent variables requiring to be advanced may be identified and more accurate strategical suggestion can be developed. 


\section{REFERENCES}

Angelidis, D., and Lyroudi. K. (2005), "The magnitude of off balance sheet activities for the evaluation of banking productivity. In International Conference on Finance, Copenhagen, September.

Boussofiane, A., R. G., Dyson, and Thanassoulis.E. (1991), “Applied data envelopment analysis.” European Journal of Operational Research, Vol. 52, No. 1, pp. 1-15.doi: 0377-2217(91)90331-O

Benli, Y. K. and Bozoklu. Ç. P. (2016), "Complexity of Measuring Advertising Efficiency: An Application of DEA Method in Turkey.” In Şule Erçetin (Ed.), Chaos, Complexity and Leadership 2014 Springer: Cham., pp. 193-207.

Charnes, A., Cooper, W. W., and Rhodes E. (1978), “Measuring the efficiency of decision making units.” European Journal of Operational Research Vol. 2, pp. 429-444.doi: 0377-2217(78)90138-8

Crémieux, P. Y., Meilleur, M. C., Ouellette, P., Petit, P., Zelder, M., and Potvin K. (2005), "Public and private pharmaceutical spending as determinants of health outcomes in Canada." Health economics Vol. 14, No. 2, pp. 107-116.doi: 10.1002/hec.922

Coelli, T.J. (1996), A Guide to DEAP Version 2.1: A Data Envelopment Analysis (Computer)Program. CEPA Working Paper 96/8, Department of Econometrics, University of New England.

Cooper, W. W., Seiford, L. M., and Tone, K. (2007), “The CCR Model and production correspondence. Data envelopment analysis: A comprehensive text with models, applications, references and DEA-Solver Software, pp. 41-85.

Deliktaş, E. (2002), “Türkiye özel sektör imalât sanayiinde etkinlik ve toplam faktör verimliliği analizi.” ODTÜ Gelişme Dergisi Vol. 29, No. 3-4, pp. 247-284.

Dormont, B., Grignon, M., and Huber. H. (2006), "Health expenditure growth: reassessing the threat of ageing.” Health economics Vol. 15, No. 9, pp. 947-963.doi: 10.1002/hec.1165

El-Shinnawy, A. (2010), “Trends of Total Factor Productivity in Egypt's Pharmaceutical Industry: Evidence from The Nonparametric Malmquist Index Approach. In ERF 16th Annual Conference, Economic Research Forum, Cairo, May.

Ersoy, K., Kavuncubasi, S., Ozcan, Y. A., and Harris J. M. (1997), “Technical efficiencies of Turkish hospitals: DEA approach.” Journal of Medical Systems Vol. 21, No. 2, pp. 67-74.doi: A:1022801222540

Frech, H. E., and Miller, R. D. (2004) "The effects of pharmaceutical consumption and obesity on the quality of life in the Organization of Economic Cooperation and Development (OECD) countries.” Pharmacoeconomics Vol. 22, No. 2, pp. 25-36.doi: 00019053-200422002-00004

Hollingsworth, B., and Parkin, D. (1997), “The efficiency of Scottish acute hospitals - An application of data envelopment analysis." Mathematical Medicine and Biology: A Journal of IMA Vol. 12 pp. 161-173.doi: 10.1093/imammb/12.3-4.161

Huang, Y.G.L. (1986), “An evaluation of the efficiency of rural primary care programs: An application of data envelopment analysis in Chapel Hill, North Carolina." PhD Diss., School of Public Health, University of North Carolina.

Huang, Y.G.L. (1990), “An application of data envelopment analysis: Measuring the relative performance of Florida general hospitals.” Journal of Medical Systems Vol. 14, pp. 191, 1990.doi: 10.1007/BF00999268

Ji, Y. B., and Lee, C. (2010), “Data envelopment analysis.” The Stata Journal Vol. 10, No. 2, pp. 267-280.

Karacabey, A.A. (2002), “Türk bankalarındaki üretim değişiklikleri ve nedenleri.” Iktisat Isletme Finans Vol. 17, No. 191, pp. $68-78$.

Kesbiç CY, Tokatlığlu, İ, Ürüt, S. (2004), "Rekabet gücü göstergeleri: Türk imalat sanayi için Veri Zarflama AnaliziMalmquist toplam faktör verimliliği endeksi uygulaması.” Iktisat Isletme Finans Vol. 19, No. 220, pp. 63-75.

Keskin Benli, Y. (2006), İstanbul Menkul Kıymetler Borsası imalat sanayi için etkinlik ve toplam faktör verimliliği analizi. Seçkin Yayıncılık: Ankara.

Keskin Benli, Y. (2012) "Data Envelopment Analysis (DEA) and Malmquist Total Factor Productivity (TFP): An Empirical Evidence in Accommodation Businesses.” Ege Akademik Bakis Vol. 12, No. 3, pp. 369.

Keskin, B. Y., and Degirmen, S. (2013), "The application of data envelopment analysis based Malmquist total factor productivity index: Empirical evidence in Turkish banking sector.” Panoeconomicus Vol. 60, No. 2, pp. 139159.doi: 10.2298/PAN1302139K 
Kirigia, J. M., Emrouznejad, A., Sambo, L. G., Munguti, N., and Liambila W. (2004), "Using data envelopment analysis to measure the technical efficiency of public health centers in Kenya." Journal of Medical Systems Vol. 28, No. 2, pp. 155-166.doi: 10.1023/B:JOMS.0000023298.31972.c9

Kooreman, P. (1994), "Nursing-home care in the Netherlands-A nonparametric efficiency analysis." Journal of Health Economics Vol. 13, pp. 345-346.doi: 10.1016/0167-6296(94)90029-9

Lexchin, J. (2001), “Lifestyle drugs: issues for debate.” Canadian Medical Association Journal Vol. 164, No. 10, pp. 14491451.

Lin, Y. H., and Hong, C. F. (2015), "Efficiency and productivity of publicly-traded bio-pharmaceutical companies in Taiwan.” In Industrial Engineering and Engineering Management (IEEM), 2015 IEEE International Conference, December, pp. 1328-1331.

Liu, J., Ding, F. Y., and Lall, V. (2000), "Using data envelopment analysis to compare suppliers for supplier selection and performance improvement.” Supply Chain Management: An International Journal Vol. 5, No. 3, pp. 143-150.doi: $10.1108 / 13598540010338893$

Majumdar, S. K. (1994), “Assessing firms capabilities - theory and measurement — as study of Indian pharmaceutical industry.” Economic Policy Weekly Vol. 29, pp. M83-M89.

Ozcan, Y. A., and Bannick, R. R. (1994), “Trends in department-of-defense hospital efficiency.” Journal of Medical Systems Vol. 18, pp. 69-83.doi: 10.1007/BF00999453

Ozcan, Y. A., Mccue, M. J., and Okasha, A. A. (1996), "Measuring the technical efficiency of psychiatric hospitals." Journal of Medical Systems Vol. 20, pp. 141-150.doi: 10.1007/BF02281992

Özdemir, E., Kılıç, S., and Aydın, Z. B. (2010), “Sosyal güvenlik reformu sonrası tüketici olarak hastaların hastane seçimi: Pazarlama açısından bir alan araştırması.” Uludağ Üniversitesi İktisadi ve İdari Bilimler Fakültesi Dergisi Sayı 29, Cilt 1, pp. 1-27.

Parkin, D., and Hollingsworth, B. (1997), "Measuring production efficiency of acute hospitals in Scotland 1991-94: Validity issues in data envelopment analysis." Applied Economics Vol. 29, No. 11, pp. 1425-1433.doi: $10.1080 / 000368497326255$

Reich, M. R. (1994), “Bangladesh pharmaceutical policy and politics.” Health Policy and Planning Vol. 9, No. 2, pp. 130143.doi: 10.1093/heapol/9.2.130

Retzlaff-Roberts, D., Chang, C. F., and Rubin, R. M. (2004), "Technical efficiency in the use of health care resources: A comparison of OECD countries.” Health Policy Vol. 69, No. 1, pp. 55-72.doi: 10.1016/j.healthpol.2003.12.002

Rüütel, D., and Pudersell, K. (2011), "Pharmaceutical policy and the effects of the economic crisis: Estonia." Eurohealth Vol. 17, No. 1, pp. 5.

Shaw, J., and Baker M. (2004), “Expert patient'—dream or nightmare?: The concept of a well-informed patient is welcome, but a new name is needed.” BMJ: British Medical Journal Vol. 328, No. 7442, pp. 723.doi: 10.1136/bmj.328.7442.723

Song, H., and Zhang, R. (2013), "R\&D efficiency appraisal of pharmaceutical industry based on DEA-Malmquist.” Journal of Chemical and Pharmaceutical Research Vol. 5, No. 11, pp. 195-199.

Thanassoulis, E., Boussfofiane, A., and Dyson, R. G. (1995), "Exploring output quality targets in the provision of perinatalcare in England using data envelopment analysis.” European Journal of Operational Research Vol. 80, pp. 588607.doi: 10.1016/0377-2217(94)00139-4

TSI (Turkish Statistical Institute) (2017), Statistics of Health Expenditure, http://www.tuik.gov.tr/PreTablo.do?alt_id=1084 accessed at 17.09.2017

Van Boeckel, T. P., Gandra, S., Ashok, A., Caudron, Q., Grenfell, B. T., Levin, S. A., and Laxminarayan, R. (2014), "Global antibiotic consumption 2000 to 2010: An analysis of national pharmaceutical sales data." The Lancet Infectious Diseases Vol. 14, No. 8, pp. 742-750.doi. 10.1016/S1473-3099(14)70780-7 